\title{
Penetapan Kelembaban, Tekstur Tanah dan Kesesuaian Lahan untuk Tanaman Kina (Chinchona spp.) di Sub Das Cikapundung Hulu Melalui Citra Satelit Landsat-TM Image
}

\author{
Abraham Suriadikusumah ${ }^{1}$ dan Aryupti Pratama ${ }^{2}$ \\ $1^{*}$ Jurusan Ilmu Tanah dan Sumberdaya Lahan \\ Fakultas Pertanian Universitas Padjadjaran \\ ${ }^{2}$ Alumni Fakultas Pertanian Universitas Padjadjaran \\ "Korespondensi: abrahamsur@yahoo.co.id
}

\author{
ABSTRACT \\ Identification of Soil Moisture, Soil Texture and Land Suitability \\ for Quinine (Chinchona spp) on Upper Sub-Watershed Cikapundung \\ Through Landsat TM Image
}

The use of Landsat TM satellite imagery has been widely used in agriculture, especially in terms of assessment or the identification of land surface cover such as vegetation, land use, slope, water puddles and streams, and other cover. This study was conducted to find out how far Landsat TM could identify soil moisture, soil texture, and land suitability analysis for quinine (Chinchona spp.) on upper sub watershed Cikapundung in Bandung District West Java at 1000-1500 m above sea level. The study was used descriptive analysis through image interpretation by Normalized Difference Soil Index Image Method, Tasseled Cap Image Transfromation: Wetness Index model, field observation /ground check and laboratory analysis. The results showed that Landsat TM image interpretation on upper sub watershed Cikapundung was capable to identify soil moisture and soil texture at accuarcy level of $57.14 \%$ and $42.85 \%$ respectively. Land characteristics on upper sub watershed Cikapundung was moderately suitable (S2) for cultivating quinine in the surface of 68,69 ha.

Keywords: Landsat-TM image, Land Suitability, Quinine.

\begin{abstract}
ABSTRAK
Penggunaan citra satelit Landsat TM telah banyak digunakan dalam bidang pertanian, terutama dalam hal penetapan atau identifikasi tutupan permukaan lahan seperti vegetasi, penggunaan lahan, kemiringan lereng, genangan air dan sungai, serta tutupan lainnya. Studi ini bertujuan untuk mengetahui sejauh mana citra satelit Landsat TM dapat mengidentifikasi kelembaban dan tekstur tanah serta analisis kesesuaian lahan tanaman kina (Chinchona spp.) pada Sub-DAS Cikapundung Hulu di Kabupaten Bandung Jawa Barat dengan ketinggian tempat 1000-1500 m di atas permukaan laut. Metode yang digunakan dalam penelitian ini adalah analisis deskriptif melalui interpretasi citra dengan membuat citra Normalized Difference Soil Index (NDSI), citra transformasi model Tasseled Cap: Wetness Index, survey lapangan dan analisis laboratorium. Hasil studi menunjukkan bahwa interpretasi citra satelit Landsat-TM dengan menggunakan pendugaan citra transformasi, dapat mengidentifikasi kelembaban tanah dengan tingkat akurasi 57,14 \% dan untuk tekstur tanah sebesar 42,85 \%. Karakteristik lahan pada Sub-DAS Cikapundung Hulu dikategorikan cukup sesuai (S2) untuk pengembangan tanaman kina dengan luasan area sebesar 68,69 ha.
\end{abstract}

Kata kunci: Citra Landsat TM, Kesesuaian Lahan, Kina. 


\section{PENDAHULUAN}

Pemanfaatan teknologi penginderaan jauh merupakan alternatif yang dapat memberikan informasi dalam perencanaan tataguna tanah yang baik karena dapat diperoleh dengan mudah, cepat, dan periodik, serta mudah dalam pengolahan datanya. Data dari penginderaan jauh satelit telah banyak digunakan untuk tujuan tertentu, antara lain seperti identifikasi penggunaan dan karakteristik lahan. Satelit merekam data secara periodik dan berkesinambungan, hal ini memungkinkan melihat kondisi karakteristik dan penggunaan lahan yang ada secara kontinyu serta memantau perubahannya, sehingga bermanfaat bagi perencanaan penggunaan lahan yang akan diterapkan.

Salah satu jenis data hasil penginderaan jauh melalui satelit adalah citra land Satelit-Thematic Mapper (Landsat-TM). Pengkajian penggunaan dan karakteristik lahan lebih efektif dan efisien jika memanfaatkan data digital citra satelit yang mempunyai saluran (band) spektral yang sensitif terhadap hal tersebut, seperti halnya dengan data yang berasal dari citra Landsat-TM. Data citra Landsat-TM merupakan salah satu sarana yang dapat digunakan dalam inventarisasi sumber daya alam, dimana dimanfaatkan dalam sembilan sektor pembangunan yang meliputi sektor pemetaan, geologi, perencanaan, studi wilayah, studi perkotaan, kehutanan, irigasi, pertanian dan pendugaan perubahan penggunaan lahan (Indroyono, 1995).

Hasil penelitian Wahyunto et al. (1995), menunjukkan bahwa penggunaan lahan, kemiringan lereng, dan erosi dapat diidentifikasi dengan baik melalui citra Landsat-TM. Hasil penelitian Nurcita (1999), menunjukkan bahwa penyebaran penggunaan lahan padi sawah dapat diidentifikasi dengan tingkat akurasi yang tinggi melalui citra LandsatTM, dan Afzal (2005), mengemukakan bahwa penggunaan lahan dapat diidentifikasi dengan baik melalui citra Landsat-TM. Hasil-hasil penelitian di atas dapat membuktikan, bahwa citra Landsat-TM mempunyai kemampuan dalam hal mengidentifikasi penggunaan dan karakteristik lahan.

Untuk kepentingan pemetaan, remote sensing hanya baik untuk tingkat ketelitian (skala) 1:50.000 atau lebih besar dari itu. Aplikasi pada pemetaan di India (Manchanda et al., 2002), memperlihatkan hasil yang kurang memuaskan dari beberapa karakteristik lahan yang diidentifikasi. Namun dalam penetapan tingkat bahaya erosi di DAS Mae Ao Thailand, penggunaan citra satelit cukup banyak membantu dan mendekati kondisi di lapangan (Hazarika et al,. 2001).

Kelembaban dan tekstur tanah adalah dua karakteristik lahan penting untuk pertumbuhan tanaman, terkait dengan penyediaan air bagi tanaman serta perkembangan akar tanaman. Dengan diketahuinya karakteristik lahan ini, maka akan memudahkan pemilihan dan penetapan komoditas yang sesuai untuk dikembangkan di suatu wilayah. Selanjutnya beberapa karakteristik lahan ini akan dikelompokkan menjadi kualitas lahan yang nilainya (besarannya) akan menentukan kelas kemampuan lahan untuk komoditas tertentu.

Sub DAS Cikapundung yang terdapat di Kawasan Bandung Utara (KBU) merupakan bagian dari DAS Citarum Hulu. Sub DAS ini bersama ke empat sub DAS lainnya, yaitu DAS Cirasea, DAS Citarik, DAS Cisangkuy, dan DAS Ciwidey telah dan sedang mengalami degradasi lingkungan yang serius, terutama meningkatnya erosi dan sedimentasi. Salah satu usaha konservasi tanah dan air dengan penanaman kina telah dikembangkan di wilayah ini dengan luasan sebesar 3.859 hektar (Dinas Perkebunan Propinsi Jawa Barat, 2003).

Tanaman kina (Chinchona spp.) merupakan tanaman perkebunan agro-industri yang memiliki nilai ekonomis. Kulit kina sejauh ini masih dibutuhkan dunia, terutama sebagai bahan obat malaria. Walaupun penyakit malaria kini dinyatakan sudah tak begitu banyak di dunia, namun berbagai produk yang membutuhkan kina sebagai bahan dasarnya masih banyak, misalnya sebagai bahan baku obat penyakit jantung, minuman ringan, garam kina, campuran bahan peledak, kosmetika, dan lainlain (Santoso et al., 2004). Mengingat banyaknya fungsi dan manfaat dari tanaman kina ini, keberadaanya harus dipertahankan dan selanjutnya dikembangkan di lahan yang sesuai. Oleh karena itu penelitian ini dilakukan untuk menentukan kemampuan citra satelit Landsat-TM dalam mengidentifikasi tekstur tanah dan kelembaban tanah, serta menganalisis kemampuan lahan atau daya dukung lahan untuk pengembangan komoditas perkebunan, khususnya kina di Sub DAS Cikapundung Hulu.

\section{METODE PENELITIAN}

\section{Bahan}

Kajian dilakukan di lahan pada kawasan Sub DAS Cikapundung Hulu (Cigulung-Maribaya) dengan menggunakan citra satelit Landsat-TM (2002) Path 
22 Row 65. Studi dilakukan berpedoman pada Peta Lereng (2001) skala 1 : 100.000, Peta Tanah (2001) skala 1 : 100.000, Peta Rupa Bumi Indonesia (RBI, 2001) skala $1: 100.000$ data curah hujan 10 tahun terakhir dari stasiun pengamat hujan di wilayah daerah penelitian.

\section{Analisis Citra}

Analisis citra meliputi Pre-processing/persiapan, lalu proses klasifikasi untuk ekstraksi informasi yang secara otomatis dengan menggunakan nilai digital. Selanjutnya pembuatan citra Normalized Difference Vegetation Index (NDVSI), yang ditujukan untuk memisahkan lahan menurut vegetasi, dengan rumus:

$$
\mathrm{NDVI}=(\mathrm{SWIR}-\mathrm{NIR}) /(\mathrm{SWIR}+\mathrm{NIR})
$$

dimana:

SWIR = short wave infrared (saluran inframerah pendek, saluran 5 dan 7)

NIR = near infrared (saluran inframerah dekat, saluran 4)

Nilai indeks mempunyai rentang -1.0 hingga 1.0. Nilai yang mewakili vegetasi pada rentang $<-0.1$ sedangkan > 0.1 mewakili tanah tanpa tutupan lahan. Berikutnya adalah pembuatan citra transformasi model Tasseled Cap berdasarkan konsep Kouth \& Thomas (1976) yang dirancang untuk memantau daerah pertanian (Purwadhi, 2001). Model Tasseled Cap didasarkan pada bidang dasarnya yaitu bidang lahan dengan nilai kecerahan tanah. Wetness Index adalah salah satu model yang terdapat pada Tasseled Cap khusus untuk penilaian kelembaban tanah. Rumus Wetness Index Tasseled Cap adalah:

$$
\begin{aligned}
& \mathrm{I}_{1}{ }^{*}(0.1393)+\mathrm{I}_{2}{ }^{*}(0.2249)+\mathrm{I}_{3}{ }^{*}(0.4036)+ \\
& \mathrm{I}_{4}{ }^{*}(0.2517)+\mathrm{I}_{5}{ }^{*}(-0.7013)+\mathrm{I}_{6}{ }^{*}(-0.4573)
\end{aligned}
$$

Dimana: $\mathrm{I}_{1}=$ Band 1, $\mathrm{I}_{2}=$ Band 2, $\mathrm{I}_{3}=$ Band 3, $\mathrm{I}_{4}=$ Band 4, $\mathrm{I}_{5}=$ Band $5, \mathrm{I}_{6}=$ Band 6

\section{Survey dan Pengamatan Lapangan}

Survey lapangan dilakukan untuk mngetahui dan menguji hasil interpretasi citra terhadap identifikasi karakteristik lahan. Penentuan titik-titik pengamatan pada survai lapangan dilakukan pada titik yang dinilai dapat mewakili area tersebut dengan mengambil $10 \%$ dari area penelitian. Pengamatan lapangan dilakukan dalam bentuk pemboran tanah dan pengambilan sampel tanah, pengumpulan data iklim, dan wawancara dengan penduduk di daerah penelitian.

\section{Analisis Laboratorium}

Sampel tanah hasil pengeboran akan dianalisis untuk mengetahui kelas kelembaban tanah, kelas tekstur dan informasi tingkat kesuburan tanah yang diminta oleh persyaratan tumbuh tanaman cengkeh. Informasi lain yang didapatkan dari peta-peta tematik, survey lapangan, dan data-data sekunder, selanjutnya dianalisis sehingga diketahui kualitas suatu lahan.

\section{Analisis Kesesuaian Lahan Untuk Tanaman Kina}

Kesesuaian lahan untuk tanaman kina dilakukan dengan mengikuti metode kesesuaian lahan dari Pusat Penelitian Tanah dan Agroklimat (2003). Kesesuaian lahan ini ditetapkan melalui penilaian terhadap kualitas lahan dari suatu daerah dengan persyaratan tumbuh suatu tanaman melalui sistem "matching" (Hardjowigeno $d k k ., 2007$ )

\section{Pemetaan/Penyebaran Spasial}

Pemetaan dan penyebaran spasial karakteristik lahan dilakukan dengan menggunakan program Sistem Informasi Geografis ArcGis V.9.3.

\section{HASIL DAN PEMBAHASAN}

\section{Kondisi Umum Daerah Penelitian}

Sub-DAS Cigulung-Maribaya merupakan Sub-DAS bagian utara dan barat DAS Cikapundung yang secara administratif berada di Kecamatan Lembang Kabupaten Bandung dan melewati tiga desa, yaitu Desa Mekarwangi, Cibodas, dan Suntenjaya. Sungai mempunyai debit maksimum rata-rata $7.16 \mathrm{~m}^{3}$ per detik per tahun (Krishna et al., 2007). Secara geografis Sub-DAS Cigulung-Maribaya terletak pada 107³8’55” BT dan 6 $6^{\circ} 49^{\prime} 18^{\prime \prime}$ LS dengan luas 3498,467 ha.

Kondisi iklim Kecamatan Lembang termasuk tipe iklim C (agak basah) menurut klasifikasi Schmidt-Fergusson. Curah hujan rata-rata dalam 10 tahun terakhir adalah $1.896 \mathrm{~mm}$ per tahun, dengan curah hujan terendah $1377 \mathrm{~mm}^{\text {tahun }}{ }^{-1}$ dan tertinggi $2.610 \mathrm{~mm}^{-1}$ tahun $^{-1}$. Besarnya curah hujan yang ada di lokasi penelitian ini cukup untuk memenuhi kebutuhan tanaman akan air, namun karena lokasi yang berlereng menuntut kehatihatian di dalam usaha tani dan pengolahan tanahnya (Kartasapoetra $d k k$., 1986). Musim hujan berlangsung pada bulan November sampai dengan April, dan musim kemarau pada bulan Juni sampai dengan Oktober, dengan suhu $20^{\circ} \mathrm{C}-21^{\circ} \mathrm{C}$. Tingkat kelembaban udara berkisar antara $83 \%$ s/d $88 \%$. 
Tanah yang berada di lokasi penelitian didominasi oleh ordo Andisol dan Inceptisol.

\section{Penentuan Kelembaban Tanah}

Analisis citra model Tasseled Cap mengklasifikasikan kelembaban tanah menjadi beberapa kelas: tanah basah, tanah lembab, tanah kering; berdasarkan pada perbedaan warna dari nilai digitalnya. Semakin besar nilai digital maka menunjukan kelembaban tanah yang tinggi, karena semakin terang warna yang dihasilkan (Gambar 1). Air lebih banyak menyerap gelombang inframerah dekat dan gelombang merah, tetapi lebih banyak memantulkan gelombang biru dan hijau, sehingga air nampak biru atau biru kehijauan. Adanya air dalam sedimen terlarut (tanah), akan memantulkan gelombang yang lebih panjang (gelombang inframerah dekat), sehingga tampak lebih terang.

Dari hasil analisis laboratorium, kelas kelembaban tanah ini berhubungan erat dengan nilai $\mathrm{pF}$, yakni tanah basah dengan nilai $\mathrm{pF}>2,54$, tanah lembab dengan $\mathrm{pF}$ antara 2,54-4,2; dan tanah kering memiliki nilai $\mathrm{pF}>4,2$. Pengelompokkan kelembaban tanah ditujukan untuk mengetahui kesediaan air tanah untuk tanaman.

Identifikasi kelembaban permukaan tanah hasil interpretasi citra satelit, selanjutnya di diuji dan dibandingkan dengan hasil penetapan di laboratorium untuk mengetahui akurasi citra terhadap karakteristik lahan ini (Tabel 1).
Tabel 1. Perbandingan Kelas Kelembaban Tanah

\begin{tabular}{cccccl}
\hline \multirow{2}{*}{ No } & \multirow{2}{*}{$\begin{array}{c}\text { Kode } \\
\text { sampel }\end{array}$} & $\begin{array}{c}\text { Kadar } \\
\text { air }\end{array}$ & \multicolumn{2}{c}{ Kelas Kelembaban } & Tabel \\
\cline { 4 - 5 } & & & Citra & \\
\hline 1 & $\mathrm{~K}_{2}$ & $45,07 \%$ & Basah & Basah & Sesuai \\
2 & $\mathrm{~K}_{3}$ & $42,06 \%$ & Basah & Basah & Sesuai \\
3 & $\mathrm{~K}_{4}$ & $20,32 \%$ & Lembab & Kering & Tidak sesuai \\
4 & $\mathrm{~K}_{5}$ & $29,70 \%$ & Lembab & Kering & Tidak sesuai \\
5 & $\mathrm{~K}_{6}$ & $30,80 \%$ & Lembab & Lembab & Sesuai \\
6 & $\mathrm{~K}_{7}$ & $28,30 \%$ & Lembab & Lembab & Sesuai \\
7 & $\mathrm{~K}_{8}$ & $65,70 \%$ & Basah & Lembab & Tidak sesuai \\
\hline
\end{tabular}

Dari tujuh sampel yang dianalisis, hanya empat sesuai dengan hasil identifikasi citra sehingga tingkat keakuratan citra transformasi model Tasseled Cap adalah 57,14 \%. Tingkat akurasi tersebut rendah, di bawah tingkat akurasi minimal $80 \%$.

\section{Penentuan Kelas Tekstur Tanah}

Gambar 2. menunjukan citra model Tasseled Cap yang sudah dibagi menjadi 3 kelas kelembaban akan dijadikan dasar untuk penentuan kelas tekstur akan mengikuti kelas kelembaban tanah, dengan asumsi tanah tanah yang bertekstur halus akan mempunyai kelembaban yang tinggi sedangkan tanah bertekstur kasar sebaliknya. Pembagian tekstur adalah agak halus untuk tanah basah, sedang untuk tanah lembab dan agak kasar untuk tanah kering.

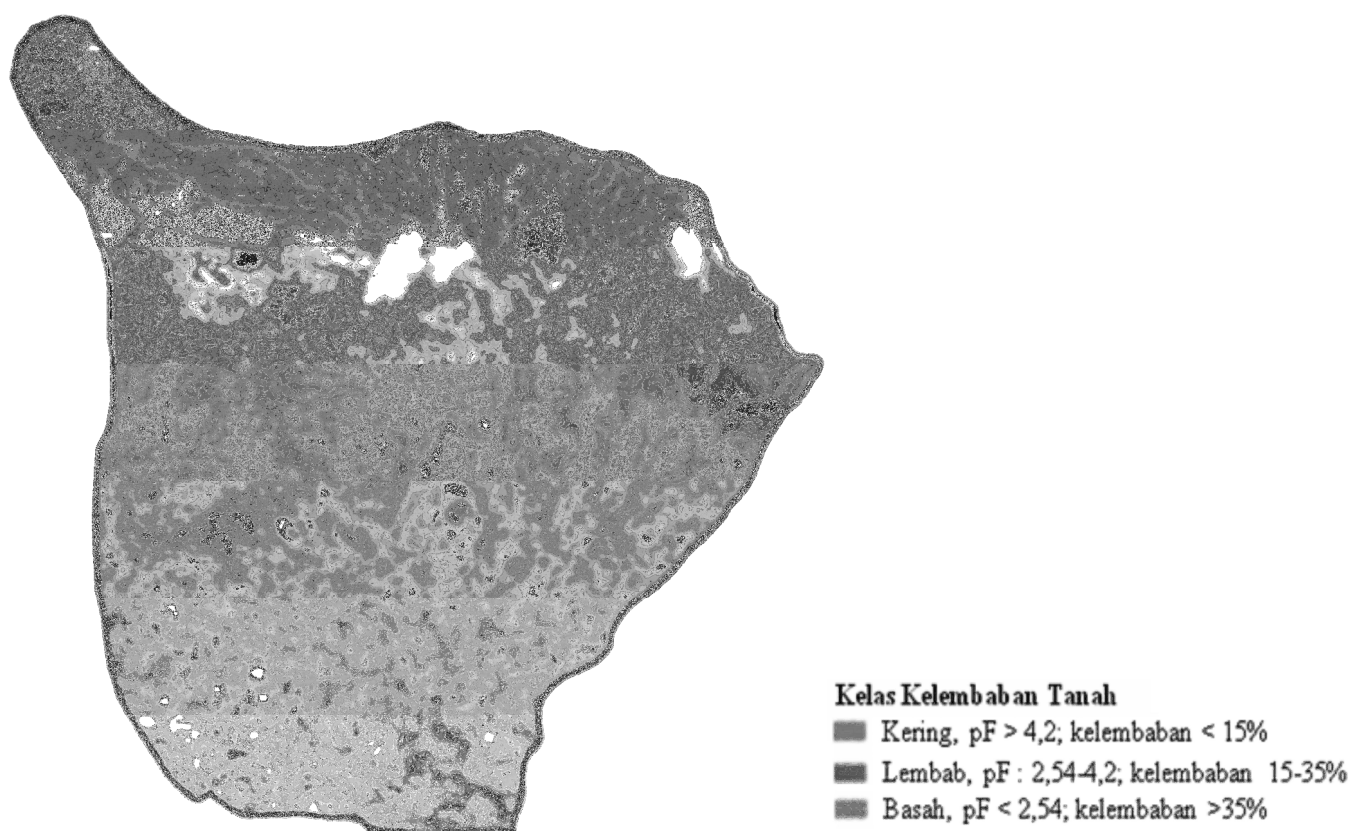

Gambar 1. Peta tematik berdasarkan kelas kelem baban tanah 




Gambar 2. Pengelompokan Tekstur Tanah di Area Penelitian

Proses penilaian akurasi untuk tekstur dilakukan berdasa rkan pada tingkat kelembabannya, dengan asumsi semakin besar kandungan airnya maktekstur tanah akan semakin halus. Lempung dikategorikan ke dalam tekstur agak halus, sedang, agak kasar, maka penilaian pun hanya dikategorikan ke dalam tiga kelas tersebut. Perbandingan kelas tektur yang diperoleh dari tingkat kelembaban hasil analisis citra Tasseled Cap dengan sampel tanah hasil analisis laboratorium yang telah disesuaikan dengan segitiga kelas tekstur terdapat pada Tabel 2.
Dari tujuh sampel yang dianalisis hanya tiga yang sesuai dengan hasil identifikasi citra atau hasil yang dilihat berdasarkan tingkat kelembabannya. Dengan akurasi 42.85 \% maka tingkat akurasi citra dalam mengidentifikasi tekstur tanah adalah rendah, di bawah tingkat akurasi minimal yang baik yaitu 80 persen.

Penilaian kelembaban tanah yang seterusnya diturunkan menjadi penilaian kelas tekstur tanah, tidak hanya berdasarkan kepada perubahan nilai digital pada model citra Tasseled

Tabel 2. Perbandingan Kelas Testur Tanah

\begin{tabular}{|c|c|c|c|c|c|}
\hline \multirow{2}{*}{ No } & \multirow{2}{*}{ Kode sampel } & \multirow{2}{*}{ Hasil analisis } & \multicolumn{2}{|c|}{ Kelas Tekstur } & \multirow{2}{*}{ Penilaian } \\
\hline & & & Segitiga tekstur & Kelembaban & \\
\hline 1 & $\mathrm{~K}_{2}$ & Lempung liat berpasir & agak halus & agak halus & Masuk \\
\hline 2 & $\mathrm{~K}_{3}$ & Lempung liat berpasir & agak halus & agak halus & Masuk \\
\hline 3 & $\mathrm{~K}_{4}$ & Lempung berpasir & agak kasar & agak kasar & Masuk \\
\hline 4 & $\mathrm{~K}_{5}$ & Lempung liat berpasir & agak halus & agak kasar & Tidak masuk \\
\hline 5 & $\mathrm{~K}_{6}$ & Lempung liat berpasir & agak halus & sedang & Tidak masuk \\
\hline 6 & $\mathrm{~K}_{7}$ & Lempung berpasir & agak kasar & sedang & Tidak masuk \\
\hline 7 & $\mathrm{~K}_{8}$ & Lempung liat berpasir & agak kasar & sedang & Tidak masuk \\
\hline
\end{tabular}


Cap saja, mengingat metode ini hanya berdasarkan nilai digital yang keluar atau dipantulkan oleh obyek. Banyak parameter yang bisa mempengaruhi tingkat akurasi dalam penilaian kelembaban tanah, antara lain suhu, curah hujan/tahun, lereng, bahan organik, sudut elevasi matahari dan lamanya penyinaran.

Penginderaan jauh (Landsat-TM) hanya sebuah media yang kita dapat manfaatkan dalam penilaian karkteristik lahan secara umum. Selain itu kita dapat mengurangi biaya survei yang tinggi meskipun observasi lapangan mutlak diperlukan.

\section{Kesesuaian Lahan Untuk Tanaman Kina}

Terdapat 12 Satuan Peta Lahan (SPL) di daerah penelitian hasil dari tumpang-susun (overlay) antara Peta Tanah, Peta Lereng, dan Peta Penggunaan Lahan masing pada skala yang sama (1:100.000) untuk dinilai kesesuaian lahannya pada tingkat kelas. Seluruh SPL memiliki faktor pembatas, baik faktor pembatas permanen maupun faktor pembatas sementara pada beberapa karakteristik/kualitas lahannya. SPL yang mempunyai karakteristrik lahan yang tidak dapat diperbaiki, tidak akan mengalami perubahan kelas kesesuaian, SPL ini dapat dikatakan mempunyai faktor pembatas permanen, sedangkan yang dapat diperbaiki, kelas kesesuaian lahannya dapat berubah menjadi satu atau dua tingkat lebih baik.

Proses penilaian kesesuaian lahan dilakukan pada tingkat kelas dengan mencocokan karakteristik lahan yang ada pada setiap SPL dengan karakteristik lahan yang diperlukan untuk tanaman kina di setiap SPL (Pusat Penelitian dan Pengembangan Tanah dan Agroklimat, 2003). Hasil penilaian kesesuaian lahan dapat dilihat pada Tabel 3.

Satuan Peta Lahan 3, 5, 6, 7 dan 12 berdasarkan kriteria kesesuaian lahan tanaman kina termasuk kelas tidak sesuai (N) karena memiliki faktor pembatas permanen yang sifatnya sangat sulit diatasi atau tidak ekonomis untuk diperbaiki yaitu kemiringan lereng yang lebih dari $30 \%$. Begitu juga halnya dengan SPL 9 yaitu termasuk kelas $\mathrm{N}$ dengan faktor pembatas permanen berupa kedalamam efektif tanah yang dangkal dan bahaya erosi yang sangat berat.

Satuan Peta Lahan 1, 2 dan 4 termasuk kelas sesuai marginal (S3) dengan faktor pembatas $\mathrm{pH}$ tanah. Kemasaman tanah bukan faktor pembatas permanen dan dapat diperbaiki dengan cara pengapuran. Dengan demikian kelas kesesuaian lahan SPL tersebut berpotensi untuk berubah satu tingkat lebih baik yaitu kelas cukup sesuai (S2) atau bahkan dua tingkat lebih baik menjadi kelas sangat sesuai (S1). Peningkatan ini terutama jika pengelolaan yang lain seperti pemupukan dilakukan juga untuk meningkatkan $\mathrm{pH}$ tanah sampai tingkat optimal untuk ditanami kina yaitu 5,8. SPL 8, 10,dan 11 termasuk kelas cukup sesuai (S2), namun memiliki faktor pembatas permanen yaitu kedalaman efektif dan tekstur sehingga tidak berpotensial menjadi kelas sangat sesuai (S1).

Dengan tersedianya informasi kesesuaian lahan untuk tanaman kina di setiap SPL, maka luas lahan yang dapat diusahakan atau dikembangkan untuk tanaman ini adalah (Gambar 3) 1.499,963 ha yang termasuk kelas tidak sesuai $(\mathrm{N}), \quad 557,031$ ha yang sesuai marginal (S3) tetapi berpotensial menjadi cukup sesuai (S2), dan 1.441,351 ha yang cukup

Tabel 3. Kesesuaian Lahan Tanaman Kina Pada Setiap Satuan Peta Lahan

\begin{tabular}{|c|c|c|c|c|}
\hline \multirow{2}{*}{ No } & \multirow{2}{*}{ Satuan Peta Lahan } & \multirow{2}{*}{ Luas $(\mathrm{Ha})$} & \multicolumn{2}{|c|}{ Kelas Kesesuaian } \\
\hline & & & Aktual & Potensial \\
\hline 1 & Hutan, Kemiringan $15-30 \%$, Incepticol & 95,438 & S3 & S2 \\
\hline 2 & Hutan, Kemiringan $15-30 \%$, Andisol & 65,404 & S3 & S2 \\
\hline 3 & Hutan, Kemiringan $>30 \%$, Andisol & 213,32 & $\mathrm{~N}$ & $\mathrm{~N}$ \\
\hline 4 & Hutan Pinus, Kemiringan $15-30 \%$, Andisol & 396,189 & S3 & S2 \\
\hline 5 & Semak Belukar, Kemiringan $>30 \%$, Andisol & 106,568 & $\mathrm{~N}$ & $\mathrm{~N}$ \\
\hline 6 & Hutan Pinus, Kemiringan $>30 \%$, Andisol & 152,705 & $\mathrm{~N}$ & $\mathrm{~N}$ \\
\hline 7 & Tegalan, Kemiringan $>30 \%$, Andisol & 599,280 & $\mathrm{~N}$ & $\mathrm{~N}$ \\
\hline 8 & Tegalan, Kemiringan 3-8 \%, Andisol & 260,951 & S2 & S2 \\
\hline 9 & Tegalan, Kemiringan $15-30 \%$, Andisol & 77,036 & $\mathrm{~N}$ & $\mathrm{~N}$ \\
\hline 10 & Tegalan, Kemiringan $0-3 \%$, Andisol & 441,276 & S2 & S2 \\
\hline 11 & Tegalan, Kemiringan 8 - $15 \%$, Andisol & 739,124 & S2 & S2 \\
\hline 12 & Hutan, Kemiringan $>30 \%$, Inceptisol & 351,054 & $\mathrm{~N}$ & $\mathrm{~N}$ \\
\hline
\end{tabular}




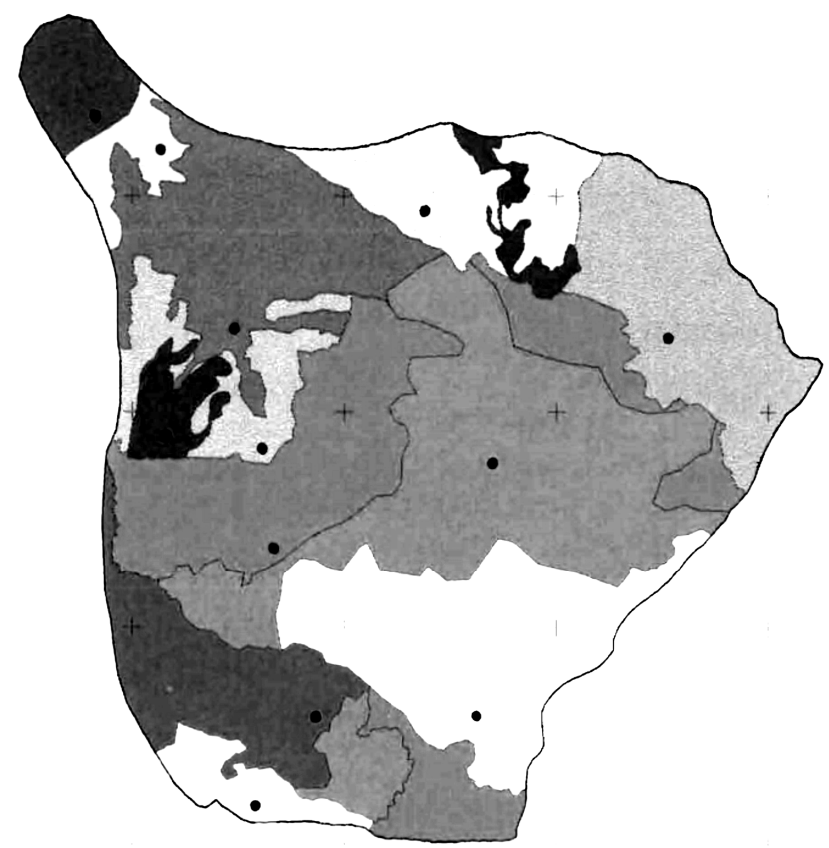

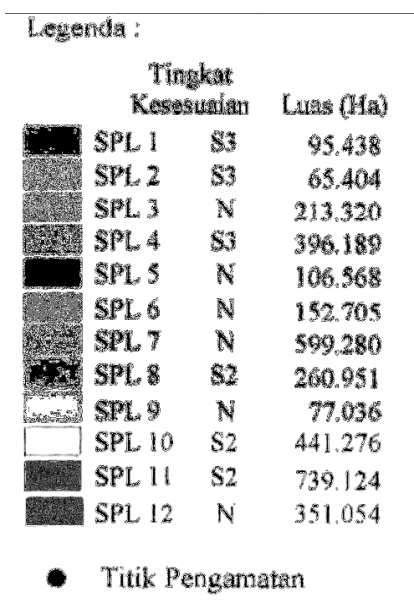

Gambar 3. Peta kesesuaian lahan SPL untuk tanaman kina di Sub-DAS Cigulung-Maribaya

sesuai (S2) tetapi tidak potensial menjadi sangat sesuai $(\mathrm{S} 1)$.

\section{SIMPULAN DAN SARAN}

\section{Simpulan}

Interpretasi citra satelit Landsat-TM dapat mengidentifikasi kelembaban tanah dan tekstur tanah pada sub-DAS Cikapundung masing-masing dengan tingkat akurasi $57.14 \%$ dan $42.85 \%$, lebih rendah daripada tingkat akurasi minimal. Di daerah penelitian terdapat $1.998,382$ ha lahan yang sesuai diusahakan atau dikembangkan untuk tanaman kina dengan tingkat kelas kesesuaian lahan sesuai marginal (S3) tetapi berpotensial menjadi cukup sesuai (S2) seluas 557,031 ha, dan cukup sesuai (S2) tetapi tidak potensial menjadi sangat sesuai (S1) seluas 1.441,351 ha. Lahan yang tidak sesuai untuk diusahakan atau dikembangkan tanaman kina seluas $1.499,963$ ha.

\section{Saran}

Sebaiknya dilakukan penelitian serupa dengan menggunakan metode yang lebih akurat dengan memasukan variabel lain seperti topografi, sudut elevasi matahari, lamanya penyinaran dan faktorfaktor lain yang mempengaruhi kelembaban tanah. Perlu dilakukan penilaian kesesuaian lahan dengan karakteristik lahan yang lebih detil baik secara fisik maupun ekonomi sehingga dapat dijadikan rekomendasi kepada para pemilik lahan untuk mengelola lahan miliknya.

\section{DAFTAR PUSTAKA}

Afzal, M. 2005. Identifikasi Penggunaan Lahan Melalui Interpretasi Citra Landsat-TM di Kecamatan Pamijahan Kab. Bandung. Skripsi (tidak dipublikasikan) Fakultas Pertanian Unpad. Bandung.

Hardjowigeno, S dan Widiatmaka. 2007. Evaluasi Kesesuaian Lahan dan Perencanaan Tataguna Lahan. Gadjah Mada University Press. 352 halaman.

Hazarika, M Kumar and K Honda. 2001. Estimation of soil erosion using remote sensing and GIS, its valuation and economic implications on agricultural production. Proceeding of 10th International Soil Conservation Organization Meeting in Purdue University, pp.: 1090-1093; editors: D.E. Stott, R.H. Mohtar and G.C. Steinhardt.

Indroyono, S. 1995. Remote sensing technology in Indonesia. CV. Script. Yogyakarta. 348 pp.

Kartasapoetra, AG. 1986. Klimatologi: Pengaruh iklim Terhadap Tanah dan Tanaman, Bumi Aksara. Jakarta. 134 halaman.

Krishna, NP dan P Oktavtia. 2007. Pengelolaan Sumber Daya Air Terpadu Melalui Pengembangan Kebijakan Pembangunan Berkelanjutan di Cekungan Bandung. Jurnal 
Perencanaan Wilayah dan Kota, Vol. 18 No. 2 Agustus 2007; hal.: 1-32. Institut Teknologi Bandung.

Kuehn, F. 2000. Introductory Remote Sensing Principles and Concepts. Routledge. 215 pp.

Lillesand, TM and RW Kiefer. 1994. Remote Sensing And Image Interpretation, 3rd Ed. John Wiley \& Sons, New York. 750 pp

Manchanda, ML, M Kudrat and AK Tiwari. 2002. Soil survey and mapping using remote sensing. Tropical Ecology 43: 61-74.

Martin, D and S. K. Saha. 2009. Land evaluation by integrating remote sensing and GIS for cropping system analysis in a watershed. Current Science 96:569-575.

Nurcita, L. 1999. Identifikasi Beberapa Karakteristik Lahan Untuk Evaluation Lahan Padi Sawah Melalui Citra Satelit Landsat-TM di Kec. Ciaranjang - Kab. Cianjur. Skripsi Fakultas Pertanian, Universitas Padjadjaran (tidak dipublikasikan). Bandung.

Poerbandono, A Basyar, A. B. Harto dan P. Rallyanti. 2006. evaluasi perubahan perilaku erosi daerah aliran sungai Citarum Hulu dengan pemodelan spasial. Jurnal Infrastruktur dan Lingkungan Binaan, 2:21-28.

Purwadhi, SH. 2001. Interpretasi Citra Digital. Gramedia Widiasarana Indonesia. Jakarta. 365 hal.

Pusat Penelitian dan Pengembangan Tanah. 2003. Petunjuk Teknis Evaluasi Lahan untuk Komoditas Pertanian. Balai Penelitian Tanah. Bogor. 154 hal.

Santoso, J, N Toruan-Mathius, U Sastraprawira, G Suryatmana dan D Saodah. 2004. Perbanyakan tanaman kina Cinchona ledgeriana Moens. dan C. succirubra Pavon melalui penggandaan tunas aksiler. Menara Perkebunan, 7211-27.

Sitorus, RPS. 1985. Evaluasi Svmberdaya Lahan. Tarsito. Bandung.

Sukarman dan A Hidayat. 2005. Pemanfaatan citra satelit dan model elevasi digital untuk inventarisasi sumberdaya lahan. Jurnal Sumberdaya Lahan, 1:20-31.

Thine, C. 2004. Application of GIS and remote sensing in characterization of soil hydraulic properties for soil physical quality assessment. Project Report, colaboration of Kenya Agriculture Research Institute World Agroforestry Centre. University of Nairobi. Kenya.

Wadsworth, R and J Treweek. 1999. Geographical Information System for Ecology: An Introduction. Addison Wesley Longman. 234 pp.

Wahyunto, H, H Djohar dan Marsudi. 1995. Analisis data penginderaan jauh untuk mendukung identifikasi dan inventariasai lahan sawah di daerah Jawa Barat dalam Prosiding Pertemuan Teknis Penelitian Tanah dan Agroklimat, hal: 37-49. Pusat Penelitian Tanah dan Agroklimat. Bogor. 


\section{Indeks}

Agen polinator, 13

Andisol, 46

Antesis, 16

Antraknosa, 13

Arang sekan, 39

Azotobacter, 46

Capnodium sp., 31, 33

Citra landsat TM, 85

Citra transformasi, 85

Colletotrichum sp., 31, 33

Deteksi transgen, 62

Eksopolisakarida, 46

Embun jelaga, 31

Embun tepung, 31

Faktor laten, 21

Fase perkembangan buah, 18

Fosfor, 56

Fungi mikoriza arbuskula, 39

Fusarium chlamydosporum, 56, 57

Fusarium oxysporum, 56, 57

Fusarium solani, 56, 57

Gigaspora sp., 39

Globodera rostochiensis, 56

Glomus sp., 39

Glu-1Dx5, 62

Gluten, 62

Hawar daun kelabu, 31

Hermaprodit, 13

Humanware, 27

Infoware, 28

Inokulum FMA, 39

Intensitas penyakit, 31

Inventarisasi penyakit, 31

Jamur parasit nematoda, 56

Jarak pagar, 31

Kabupaten Keereom, 77

Kadmium, 46

Kalium, 56

Kelembaban tanah, 85

Kentang, 56, 57

Kina, 85

Kubis, 36

Karakteristik lahan, 5, 85

Kesesuaian lahan, 7
Koperasi unit desa, 21

Layu bakteri, 31

Media tumbuh, 39, 51

Manajemen, 21

Morfologi bunga, 15

Nematoda, 31

Nematoda sista kuning, 56

Morfologi bunga dan buah, 13

Oidium sp., 31, 33

Orgaware, 28

Pabrik pupuk organik, 68

Padi putatif transgenik, 62

Palem putri, 51

Pasir, 53

Pengendalian hama terpadu, 57

Polymerase Chain Reaction, 61, 62

Perkebunan, 5

Perkembangan bunga dan buah, 13

Pertumbuhan biji, 51

Pestalotiopsis sp., 31, 33

Phaecilomyces lilacinus, 56, 57

Plant Growth Promoting Rhizobacteria, 48

Podsolik merah kuning, 51

Produksi Gula, 6

Protandri dikogami, 13

Pupuk hayati, 47

Pseudomonas sp., 31, 33

Remote sensing, 86

Rotylenchulus sp., 31, 33

Serangga, 19

Sistem informasi geografis, 77

Sorgum, 39

Studi kelayakan, 68

Sub DAS Cikapundung Hulu, 86

Sumber daya lahan, 5

Surian, 13

Tanaman akumulator Cd, 48

Tanaman hias, 51

Tebu, 5

Tegakan benih, 13

Tekstur tanah, 85

Zat pengatur tumbuh, 53

Zeolit, 39

Zone agro ekologi, 77 